International Journal of Linguistics, Literature and Culture
Available online at https://sloap.org/journals/index.php/ijllc/
Vol. 4, No. 3, May 2018, pages: $72 \sim 79$
ISSN: 2455-8028
https://sloap.org/journals/index.php/ijllc/article/view/182

\title{
Text of Cigarette Advertisement: A Semiology Study of Roland Barthes
}

\author{
Ahmad Abdan Syakur a \\ Rusdiawan $^{\mathrm{b}}$ \\ Muhammad Sukri ${ }^{\mathrm{c}}$
}

\section{Article history:}

Received: 10 December 2017

Revised: 10 April 2018

Approved: 20 May 2018

Published: 29 May 2018

\section{Keywords:}

Myth;

Semiotics;

Roland Barthes;

Cigarette advertisement;

\begin{abstract}
Most of the cigarette advertisements offer various concepts such as fun, style, and self-confidence. These concepts are a series of mythic buildings articulated in advertisements to replace the appearances of messages conveyed by the tobacco products. The message content of the product visuals is replaced not just by the existence of various rules or regulations that prohibit the presence of tobacco products or smoking activities. This is performed to reinforce the impression or a particular image of the product being advertised. Advertising, in the context of this research, is seen as an arena used to resolve social contradictions, offer identity models, and celebrate the existing social order. The A-Mild advertisements shown in Mataram city will be studied using the Roland Barthes Semiology approach. Thus, the use of this approach can show the myths built through signifier and signified and how the symbol of A-Mild cigarette advertisements in Mataram study affects the readers, especially youth according to Roland Barthes semiology.
\end{abstract}

2455-8028 ${ }^{\circ}$ Copyright 2018. The Author. This is an open-access article under the CC BY-SA license (https://creativecommons.org/licenses/by-sa/4.0/) All rights reserved.

\section{Author correspondence:}

Ahmad Abdan Syakur,

Faculty of Teacher Training and Education, Indonesian Language, and Local Literature

Email address: abdansyakur90@gmail.com

\section{Introduction}

The advertisement is a commercial display of a specific and particular product, and its existence is extremely easy to find anywhere. The advertisement itself has a persuasive nature where it aims at influencing and persuading consumers to buy / to consume a product being advertised. The appearance of advertisement is various, it may be

${ }^{a}$ Mataram University, Indonesia

${ }^{\mathrm{b}}$ Mataram University, Indonesia

${ }^{c}$ Mataram University, Indonesia 
printed (internet, newspapers, magazines, posters, billboards, and pamphlets) and also in the form of electronics such as advertisements showed on television. Nowadays, advertising grows proved by the higher creativity in order to get the audience attention. Advertising does not only provide a profit for the company but also become an entertaining show for the public. Especially for the youth, by the use of the text, the more creative the advertisement is made, the stronger the advertisement is remembered by the reader. This is because the text used is very close to daily life, especially the nature of confidence, sociable, adventure/experience, and face the challenges inherent in young people. Moreover, the advertisements were shown in crowded places, sports arenas and can be easily seen in the area near the school, such as A-Mild cigarette advertisement in Mataram. A research entitles Analysis of the text of cigarette advertisement in Mataram city: a semiology study of Roland Barthes aims at describing the meaning of cigarette advertisement set in Mataram through signified and signifier and describing the meaning through denotative and connotative meaning developed by Roland Barthes.

This study was conducted by employing qualitative approach since the findings are not obtained through statistical procedure or other calculation form. This type of research is interpretative, because the data found were interpreted to find the results. In this research, the data collected is data in the form of text from A Mild cigarette advertisement located in Mataram City. The object of this research is the text of $A$ Mild cigarette advertisement set in Mataram City. The method used were the method of documentation and literature study. These methods were used to document and collect the necessary data by reviewing the relevant books to achieve research objectives.

In this research, Descriptive Approach Analysis is the relevant approach used to analyze the text of $A$ Mild cigarette advertisement in Mataram. This descriptive analytical approach is an approach that describes the facts contained in a data. This approach is used to achieve the research objectives of finding ideological reconstruction and meaning analysis through relationships among lexicons. The principle of this approach is to describe or systematically describe factually and accurately the facts in the text of $A$ mild advertisement set in Mataram city.

\section{Research Methods}

\section{Theory}

The word semiotics is derived from English: semiotics. Referring to Pedoman Umum Ejaan Bahasa Indonesia yang Disempurnakan dan Pedoman Umun Pembentukan Istilah (The official Indonesian spelling and terminology development) English suffix -ics in Indonesian is changed to -ik or $i k a$. Another name for semiotics is semiology. Both of them have the same meaning that is a study of signs. Both semiotics and semiology are derived from Greek: semeion, meaning sign (Van Zoest, 1996). A linguist, Ferdinand de Saussure, tends to use the term semiology which was originally part of social psychology. The next step of de Saussure is to develop a semiology into a study of various sign systems (Teeuw in Santosa, 1990: 2). Semiology is a popular term in French, especially in language and culture.

Dik Hartoko (1984) affirms the border of semiotics that is how the literary works were interpreted by observers and the public through the signs or symbols. Furthermore, Luxemburg (1984) states that semiotics is the systematic study of the signs and symbols, its systems and the process of symbolism. Furthermore, Sutadi Wiryaatmajda (1981: 4) states that semiotics is a study examining the life of the sign in its broad meaning in society, both literal and ornamental (figurative), both language and non-language. This is sustained by the opinion proposed by Rene Wellek (1956) including image, metaphor, symbol, and myth into the scope of semiotics. In addition, Aart van Zoest (in Santosa, 1990: 3) defines semiotics as the study of signs and everything related to it: the way it functions, its relation to other signs, its delivery, and its acceptance by those who use it. Semiotics is particularly divided into three main parts, namely (1) semiotic syntax, the study of signifier concerning on its classification, in relation to other signs, and the way in which it works together to perform its functions. (2) Semantic semiotics, a study that highlights the relation of signs with reference and with the interpretation it produces; and (3) Semiotics Pragmatics, the study of signs that attaches importance to the relationship between the sign and the sender and the recipient.

In mapping a meaning, Barthes develops the sign map to see the meaning of the first level and the significance of the second level of denotation and connotation to be displayed.

Syakur, A. A., Rusdiawan, -, \& Sukri, M. (2018). Text of cigarette advertisement: A semiology study of Roland Barthes. International Journal of Linguistics, Literature and Culture, 4(3), 72-79. 


\begin{tabular}{|l|l|}
\hline 1. Signifier & 2. Signified \\
\hline
\end{tabular}

\begin{tabular}{|l|l|}
\hline 3. Denotative sign & \\
\hline 4. Connotative Signifier & 5. Connotative Signified \\
\hline
\end{tabular}

\section{Connotative Sign}

Figure 1. Roland Barthes' Sign Map Source: Paul Cobley \& Litza Jansz (1999). Introducing Semiotics. NY: Totem Books, p. 51.

Based on Barthes' map, it shows that the denotative sign (3) consists of the signifier (1) and signified (2). At the same time, however, denotative signifier are connotative signifier (4). In other words, it is a material element: only if you recognize the sign of "singa" (lion) then connotations such as self-esteem, ferocity, and courage become possible (Cobley \& Jansz, 1999: 51). In the concept of Barthes, a connotative sign not only has additional meaning but also contains the two denotative signs that underlie its existence. In fact, this is crucial contribution or finding of Barthes for the refinement of Saussure semiology which stops at the denotative level.

In more detail, linguistics basically distinguishes the level of expression (E) and the level of content (C) both linked by a relation (R). The unity of these levels and relationships form a system (ERC). Such a system exists within itself to be a simple element of a second system that extends it. Referring to Hejemslev, Barthes argues that language can be articulated into two corners of articulation (Barthes, 1983, in Kurniawan, 2001: 67)

1. Connotation

2. Denotation

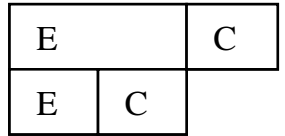

\begin{tabular}{|l|l|l|}
\hline $\mathrm{E}$ & \multicolumn{2}{|l|}{$\mathrm{C}$} \\
\hline & $\mathrm{E}$ & $\mathrm{C}$ \\
\hline
\end{tabular}

Metalanguage

Language Object

Figure 2. Two Articulation Perspectives of Barthes

Source: Barthes (1983), in Kurniawan (2001). Semiologi Roland Barthes: Mangelang: Yayasan Indonesiatera, p. 67.

In the first articulation (left), the primary system (ERC) constitutes the level of expression for the second system: (ERC) RC. Here, system 1 corresponds to the denotation level of system 2 with the degree of connotation. In the second articulation (right), the primary system (ERC) constitutes the content level for the second ER (ERC) system. Here, system 1 corresponds to the object language and system 2 with metalanguage (Kurniawan, 2001: 67).

\section{Results and Analysis}

\subsection{Signifier and Signified in A Mild Cigarette Advertisement in Mataram City}

A Mild cigarette advertisement in Mataram City would be analyzed in two stages namely, in the first stage, it can be seen in the background on (1) signifier and (2) signified. This stage is more of a denotative sign. This denotation stage just looks at the sign language. From this understanding of language, we can come to the second stage, which is to examine the sign connotatively. At this stage,e the cultural context, for example, has contributed to the study. From the data found, through this research signifier and signified of A Mild cigarette advertisement in Mataram City would be analyzed cigarette using semiology approach proposed by Roland Barthes. 
a) Analysis of signifier and signified on the text of A Mild Cigarette Advertisement" Outbound" Version. The A Mild Cigarette advertisement slogan is "KARENA LOGIKA BEDA TIPIS SAMA LO GILA" (because being logic is slightly different with being crazy). The slogan consists of words karena (because), logika (logic), beda (different), tipis (slight), sama (with), lo (you), and gila (crazy). The word karena (because) has a meaning: The connective word to mark cause or reason, Caused by; because (KBBI, 2002: 523). Knowledge of the rules of thinking. Reasonable way of thinking (KBBI, 2002: 713). The word Beda (different) means something that makes a difference (not the same) between one thing and another. Inequality. Difference (KBBI, 2002: 115). Slightly between one surface and the other (about flattened items). Less thick (about layers, paint, etc.) Less dense (about clouds, air, and so on). Less visible (about ink writing and so on), (KBBI, 2002: 1282). The word Sama (with or same) has the meaning of: similar (as it is, the circumstances, etc.), no different, no different, simultaneously, coincidently Balanced; comparable; equivalent (KBBI, 2002: 1017). You. Exclamation remarking surprised, aghast, and so forth (KBBI, 2002: 712). Sickness of memory (lack of memory); (his nerves are disturbed or his mind is not normal). Unusual; not as it should be; do nononsense (no sense). Too much; brash (used as an exclamation, effective word); admiration awe. feeling very admire. Does not make sense (KBBI, 2002: 379). As for the signified shown by the $A$ Mild advertisement in "Outbound" version featuring a man walking on a rope stretching from a height. The man walks casually though without any safety device. With a steep cliffs advertisement setting. The advertisement slogan says: "KARENA LOGIKA BEDA TIPIS SAMA LO GILA" (because being logic is slightly different with being crazy). So, the meaning to be conveyed that the person who walks on the cliff without a safety device is a person who has been logically insane. However, since this advertisement only take the conjunctive clause "karena logika beda tipis sama lo gila" meaning that logic is the same as madness.

b) The signifier indicated by A Mild Cigarette Advertisement with slogan Terjun Bebas (freefall) is "PIKIR PENDEK" (short thought). The text above consists of the word pikir (thought) and pendek (short). The word thought means: Reason; memory; wishful thinking. The word of the heart; opinion (KBBI, 2002: 891). The word pendek (short) means: Near its distance from end to end. Close distance from next door; not high. Just a moment. Concise. Brief (KBBI, 2002: 864). Thus, the overall meaning of lexical is the only reason that is possessed only briefly. Meanwhile, signified expressed in this advertisement with Terjun Bebas (freefall) version featuring a group of young people who jump free into the sea from the cliff. With setting sun setting, the advertisement slogan says: " PIKIR PENDEK" (SHORT THOUGHTS).

c) The text of A Mild cigarette advertisement in the version of Tiga Gadis Tersesat (Three Girls Lost) has a slogan saying that "MENDING TERSESAT DARIPADA NANYA " (better to be lost rather than to ask). The slogan consists of words mending (better), tersesat (getting lost), daripada (rather than), and nanya (ask). The word mending means: Better; rather good (KBBI, 2002: 760). Not through the right way. Deviate from the truth (KBBI, 2002: 1108). Daripada has a meaning: The foreground to mark the comparison (KBBI, 2002: 266). The word nanya has meaning: Request description (explanation and so on) Asked (KBBI, 2002: 1209). The lexical meaning of the slogan above is Better to get lost than to ask the way or direction to others that is not necessarily true. The illustration of A Mild cigarette advertisement of Tiga Gadis Tersesat features three young women walking on the crossroads. Around the road there is no road sign, settlement or anything. But they kept walking casually. The advertising background is bright sky, hills and brownish meadow. The ad slogan reads: "MENDING TERSESAT DARIPADA NANYA ". The meaning to be conveyed is a heresy is deviating from the truth. After experiencing the grammatical process by attaching the prefix [ter-] of the word sesat and become tersesat (becomes lost). The meaning is changed to grammatical that is salah jalan (wrong way) atau kesasar (get lost). While the word nanya formed from the basic word tanya (ask). It happens after experiencing the grammatical process with the attachment of simulfix affixed from the word tanya and become nanya meaning of asking for information or explanation. So, the overall grammatical meaning of the slogan is better to be lost rather than to ask for information.

d) The slogan of advertisement of A Mild Cigarette version Jejak Sepatu (Footsteps) is "BIAR KARYA YANG BICARA" (let the works speak out). The slogan consists of biar (let), karya (works), yang (which), berbicara (speak). The word Biar means: Never mind, allow. Connection to state unconditional things (KBBI, 2002: 153). Karya (work). The result of works Creation that is not an adaptation, copy, translation. The result of a creation that is not an imitation (525). The word yang (which) has a meaning: The word to say that the

Syakur, A. A., Rusdiawan, -, \& Sukri, M. (2018). Text of cigarette advertisement: A semiology study of Roland Barthes. International Journal of Linguistics, Literature and Culture, 4(3), 72-79. 
following word or phrase is preferred or distinguished from the other. The word used as a differentiator (KBBI, 2002: 1368). The word bicara (speak) means: Reason. Thoughts, Opinions (KBBI, 2002: 154). The lexical meaning of the ad slogan is that a person's ability is measured from the result he created not from the result of his speech. This version of A Mild's advertisement features a close-up shoe drawing in the desert while not far from the shoes there are footprints owned by a man who walked not far from the shoe. With a desert setting and hot weather, the advertisement slogan says: "BIAR KARYA YANG BICARA" (let the works speak out).

e) The A Mild's cigarette advertisement version Main Gitar (play guitar) has slogan saying "BERISIK GUE BERISI" ( my noisiness is meaningful). The slogan above consists of ribut (noisy), gue (me), and berisi (contains words). The word Berisik has a meaning: The frenzied bustle Feeling buzzing in the ear (KBBI, 2002: 144). I, me, (KBBI, 2002: 386). The word berisi has the meaning: There is content. Not empty. Not empty. Knowledgeable. Solid and strong. Contains, loads (KBBI, 2002: 459). The overall lexical meaning is that the noise makes me have content. The A Mild advertisement in this version features a man playing a guitar music on the roof of a building. With the sun setting in the afternoon, the ad slogan says: "BERISIK GUE" (my noisiness/I am noisy).

\subsection{The Meaning of Cigarette Advertising Symbols in Mataram City Slightly Suffers Young People}

Cigarette advertisement always looks different, cool often, even cooler than another advertisement. It is seen in the form of a luxurious, fashionable, and of course close to Young children. No wonder so many young people want to look like those in cigarette commercials. In cigarette advertisements, the cost incurred is taken seriously, this is not separated from the support of funds that are almost unlimited which is why cigarette advertising clever play in insight region. Insight in advertising terms is an advertisement that appropriately touches the consumer psychology. As soon as you watch the advertisement, consumers will immediately feel associated with the subjects and topics in it. Consumers will feel the same as they appear in the advertisement. In this fact, the effect is unusual, the image of the advertised product will be deeply embedded. Messages, especially brands, delivered by the cigarette in question will be inherent in the consumer's memory. And maybe, with loyal loyalty will consume the advertisement.

The theme of A Mild's cigarette advertisement is very diverse with a very close to the likes of youngsters like: Logika beda tipis dengan tho gila (being logic is slightly different with being crazy), terjun bebas (freefall), pikir pendek (short thought), Tiga Gadis Tersesat (Three Girls Lost) "mending tersesat daripada nanya" (better to be lost rather than to ask), biar karya yang bicara, (let the works speak out) and berisik gue berisi (my noisiness is meaningful). From some advertisement that has been described above provides a description that young people are people who like adventures in the wild, the achievements of music, success in the world of sports, successful sociable, easily hooked girlfriend, socially polite, miss the village when in the far, rebellious themes. all of these subjects are very typical of young people. Currently, young people become the center of cigarette industry shooting. The main target of cigarette industry is young people aged 18-30 years. But, in fact, advertising is always right for teenagers under 18 years old. In various meetings, tobacco companies emphasize that young smokers are crucial to them. Young people who are struggling to find this identity will continue to keep the cigarette advertisement business for decades to come. This is because cigarettes are strongly associated with loyalty. The cigarette industry admits it is very difficult to offer a new brand of cigarette to a cigarette addict. Therefore, young consumers who are still trying to smoke should be considered and fostered so fertile.

Young people are a very interesting subject for the cigarette industry. Various special terms are attached to this masculine market, including YAUS (young adult urban smokers) young adult female smokers (YAFS), and young adult male smokers). Many studies were done by the cigarette industry to attract young people. From this cigarette text advertisement research, it appears that the industry is keen to understand the behavior of young people. The desire to appear more mature, the desire to be accepted by peers, the desire related challenging activities, is the most appropriate entrance which is then used to target young people. As a result, we watched cigarette advertisements displaying gallant mountaineers, tough rock climbers, jungle adventures, and extreme sports bungee jumping enthusiasts. Moreover, a lot of advertisement that presents the collective life of young people with the phrase (tagline) "Asiknya ramai-ramai, dan nggak ada aloe gak ramai" (happy together and without you, we are not happy). Marketing strategies for young people must also be structured with spirit and motivation. A flat and unlimited world. Music in this case, is the most strategic entrance that must be embraced. Through this research shows that young people today have more action on the music than the print media. Music is their language, the 
source of ideas and trends of young people. No half-hearted situations like this have entered the environment of young people and cigarette industry racing to hold a music event. For the young, the festival music event is very enthralling. Imagine, there is music, friends with the same hobby, the competition with the high prize, beautiful girl, plus free cigarettes. The right blend to invite teenagers to enter the world of nicotine addictions. From this research, besides analyzing and signifier and signified contained in the advertisement of A Mild cigarettes in Mataram city, by this research we can also understand the meaning or symbol contained in the said advertisement through the study of semiology, a theory proposed by Roland Barthes.

\section{Conclusion}

Based on the research that has been accomplished signifier and signified on A Mild cigarette advertisement in Mataram city and understanding the meaning of cigarette advertisement symbol according to Roland Barthes semiotics study can be discovered and analyzed. The description of signifier and signified Myths In A-Mild Cigarette Advertisement can also be examined. In the A Mild cigarette advertisement, the concept of myth is portrayed through the concepts of style. In the level of myth, the second-tier semi-biological system, this "style" signifier refers to a sign of self-actualization: pleasure, enjoyment, and pertinence.

In this level then researchers see that the concept of self-actualization in the form: pleasure, enjoyment, pride, and confidence into the myth of the reality of life. This analogy is found by researchers presented in the advertisement of A Mild. Smoking becomes the way to channel the desire to be part of a particular social class, to be a part of the connoisseurs of pleasure, enjoyment, and self-confidence that cannot be presented in the real world. Myths are built to deceive consumers with promises of pleasure, enjoyment, and self-confidence that are intoxicating and enjoyed by young people. In the end, cigarette advertisements including $A$ Mild offer concepts of style and fun as a myth. However, researchers see that the construction done by A-Mild advertisement is a series of very subtle and implicit concepts that can make readers interested in the products advertised with various myths raised.

Conflict of interest statement and funding sources

The authors declared that they have no competing interest. The study was financed by personal funding.

\section{Statement of authorship}

The authors have a responsibility for the conception and design of the study. The authors have approved the final article.

\section{Acknowledgments}

The authors would like to thank all those who have helped in completing this research. To my parents who provide much prayer and always support morally and materially so that researchers can accomplish this research. To my wife who is always patient and still provides motivation, so this research can be resolved. My acknowledgments also go to all lecturers of master programs who have shared and taught the author sincerely and patiently. 


\section{References}

Bahri, S. (2018). Comparison of expression of God in poems written by Amir Hamzah, Chairil Anwar and Sutardji Calzoum Bachri. International Journal of Linguistics, Literature and Culture (IJLLC), 4(3), 64-71.

Budiman, K. (2002). Analisis wacana: dari linguistik sampai dekonstruksi. Diterbitkan untuk Pusat Studi Kebudayaan, Universitas Gadjah Mada, Yogyakarta oleh Kanal.

Darma, Y. A. (2009). Analisis wacana kritis. Yrama Widya bekerja sama dengan Jurusan Pendididikan Bahasa dan Sastra Indonesia (FPBS UPI).

Hamidah, L., \& Sa'diyyah, C. (2011). Analisis Simbol Iklan Rokok Dji Sam Soe Gold Edisi Halus dan Mantap (Kajian Analisis Semiotik Pendekatan Roland Barthes). Jurnal Ilmu Komunikasi, 1(2), 236-268.

Hardiman, F. B. (2004). Kritik ideologi: menyingkap kepentingan pengetahuan bersama Jurgen Habermas. Buku Baik.

Kapoor, K. (2018). Representation of Female Characters through Item Songs in Selected Hindi Movies. International Journal of Social Sciences and Humanities (IJSSH), 2(1), 1-9.

Lelland, D. M. (2005). Ideologi Tanpa Akhir, terj. Muhammad Syukri. Yogyakarta: Kreasi Wacana.

Lindayani, L. R., Masri, F. A., Idul, R., \& Sawali, L. (2018). A metaphorical analysis of Kabhanti Modero to show Munanese social relations. International Journal of Linguistics, Literature and Culture (IJLLC), 4(2), 72-80.

Pembinaan, T. P. K. P. (1994). Kamus Besar Bahasa Indonesia, Jakarta: Balai Pustaka. Cet. III.

Piliang, Y. A., \& Adlin, A. (2003). Hipersemiotika: tafsir cultural studies atas matinya makna. Jalasutra.

Prasetyaningtyas, A. (2012). Analisis semiotik dan wacana pada iklan rokok la lights "yang lain bersandiwara, gue apa adanya!" versi topeng monyet di media televisi (doctoral dissertation, universitas airlangga).

Rosyidi, M. Ikhwan dkk.(2010). Analisis Teks Sastra.

Santosa, P. (1993). Ancangan semiotika dan pengkajian susastra. Angkasa.

Sobur, A. (2017). Semiotika komunikasi. Remaja Karya.

Sunardi, S. T., Djatmiko, S., \& Minarni, A. (2002). Semiotika negativa. Kanal.

Thompson, J. B., \& Yaqin, H. (2003). Analisis ideologi: kritik wacana ideologi-ideologi dunia.

Udasmoro, W. (2007). Petualangan semiologi Roland Barthes. Yogyakarta: Pustaka Pelajar.

Wellek, R., \& Warren, A. (1995). Teori Kesusastraan: Diindonesiakan oleh Melani Budianta. Penerbit PT Gramedia Pustaka Utama. 


\section{Biography of Authors}

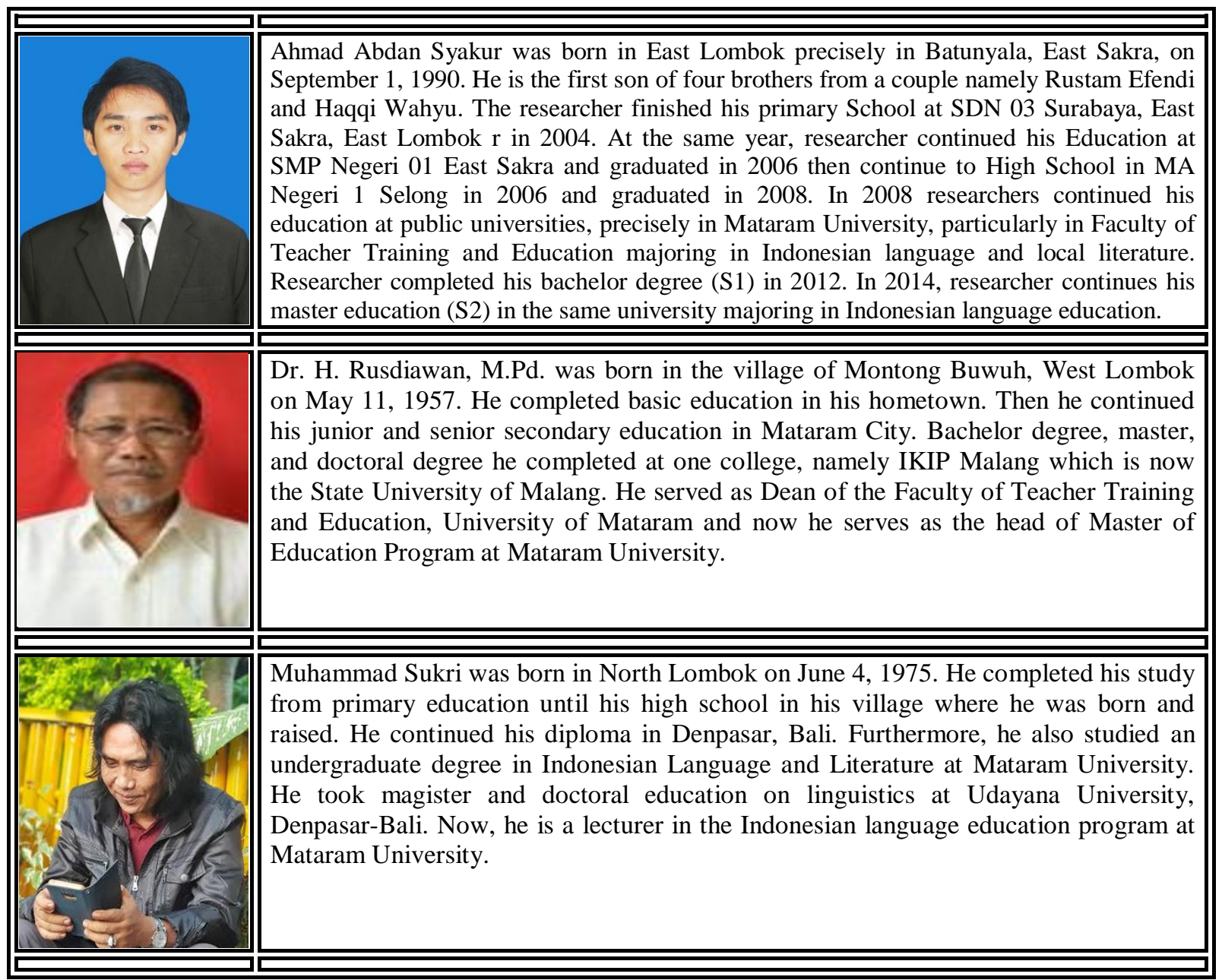

Syakur, A. A., Rusdiawan, -, \& Sukri, M. (2018). Text of cigarette advertisement: A semiology study of Roland Barthes. International Journal of Linguistics, Literature and Culture, 4(3), 72-79. https://doi.org/10.21744/ijllc.v4n3.182 